\title{
Sprawozdanie z pobytu w Ośrodku Dokumentacji i Studium Pontyfikatu Jana Pawła II w Rzymie, wrzesień-październik 2018 r.
}

Od wielu lat Naczelna Dyrekcja Archiwów Państwowych prowadzi akcję pomocy archiwom polonijnym za granicą w zakresie wsparcia merytorycznego oraz technicznego zabezpieczenia zasobu. W ramach tych działań na przełomie września i października 2018 r. w Ośrodku Dokumentacji i Studium Pontyfikatu Jana Pawła II w Rzymie przebywała Anna Chursan z Archiwum Państwowego w Lublinie.

Celem działalności ośrodka, będącego częścią założonej w roku 1981 watykańskiej Fundacji Jana Pawła II, jest gromadzenie materiałów dokumentujących dzieło pontyfikatu papieża Jana Pawła II. W oparciu o zgromadzone zbiory realizowane były m.in. publikacje i projekty wydawnicze dotyczące zarówno nauczania papieskiego, jak i problematyki Kościoła w Polsce.

Podczas miesięcznego pobytu zapoznano się z warunkami przechowywania zbiorów archiwalnych oraz dokonano wstępnej oceny samego zasobu pod względem zawartości, opracowania materiałów archiwalnych i technicznego stanu zachowania.

Charakter zbiorów archiwalnych ośrodka plasuje go w gronie archiwów społecznych. Jego zasób stanowią gromadzone przez pracowników ośrodka maszynopisy oraz kopie rękopisów homilii, przemówień i wystąpień publicznych Karola Wojtyły głoszonych w trakcie wizytacji duszpasterskich i uroczystości kościelnych w archidiecezji krakowskiej od lat 60. XX w., relacje i sprawozdania $\mathrm{z}$ uroczystości religijnych, w tym obchodów milenijnych, korespondencja z władzami PRL, a także teksty wystąpień wygłaszanych w czasach pontyfikatu, m.in. podczas podróży apostolskich, audiencji generalnych, modlitw Anioł Pański, jak również listy apostolskie oraz redagowane wersje encyklik. Dokumentację aktową uzupełniają przekazywane w darze przez instytucje i osoby prywatne nagrania dźwiękowe i audiowizualne. Są to przede wszystkim nagrania dokumentujące wydarzenia $\mathrm{z}$ udziałem Jana Pawła II, pielgrzymki, nabożeństwa i uroczystości religijne, przemówienia, oficjalne spotkania oraz zapisy koncer- 
tów, przedstawień teatralnych, wystaw i utworów dedykowanych papieżowi. Znaczącą częścią zasobu jest zbiór ponad 200 albumów i kilkunastu tysięcy fotografii luźnych. Obraz pontyfikatu dopełnia dokumentacja aktowa oraz nagrania dźwiękowe związane z organizacją i przebiegiem odbywających się corocznie w Castel Gandolfo interdyscyplinarnych sympozjów z udziałem przedstawicieli nauki polskiej oraz międzynarodowych konferencji współorganizowanych przez Instytut Nauk o Człowieku w Wiedniu. Warto również wspomnieć o spuściznach przekazanych przez wieloletnią bliską współpracownicę Jana Pawła II urszulankę s. Emilię Erlich i francuskiego korespondenta przy Stolicy Apostolskiej o. Josepha Vandrisse'a, a także o materiałach przekazywanych przez kard. Stanisława Dziwisza. Interesującym zbiorem jest Rassegnastampa, czyli przygotowywany przez Sekretariat Stanu Stolicy Apostolskiej przegląd prasy międzynarodowej, a od roku 2000 również przegląd informacji publikowanych w Internecie. Doskonale ilustruje on krąg zainteresowań Watykanu i postrzeganie przezeń aktualnej problematyki w sferze polityczno-społeczno-religijnej. Dzięki darom zgromadzony zasób znacznie wykracza poza ramy działań statutowych ośrodka. W wydzielonym zbiorze dokumentów z XVII-XX w. znajduje się m.in. korespondencja władców polskich z przedstawicielami Stolicy Apostolskiej, czy chociażby skrypt dłużny opiewający na dwa tysiące dukatów pożyczonych przez króla Augusta II od nuncjusza apostolskiego na naprawę twierdzy kamienieckiej, a także prowadzona w początkach XVIII w. korespondencja dyplomatyczna przedstawicieli Kościoła greckokatolickiego w Rzeczypospolitej ze Stolicą Apostolską.

Zbiory ośrodka to obok archiwum również zawierająca wiele cennych wydawnictw biblioteka oraz muzeum. Wśród unikatowych starodruków do najcenniejszych należy drugie wydanie Biblii ks. Wujka z 1594 r. Zasoby muzeum stanowią dary ofiarowane bezpośrednio Ojcu Świętemu. Są wśród nich cenne dzieła sztuki wręczane podczas oficjalnych spotkań i uroczystości kościelnych, a także wiele darów o charakterze wybitnie emocjonalnym - jak chociażby cenne pamiątki rodzinne wyniesione $\mathrm{z}$ niemieckich więzień, obozów i sowieckich łagrów.

Zgromadzone $\mathrm{w}$ archiwum ośrodka materiały nie zostały jeszcze zarchiwizowane w pełnym tego słowa znaczeniu. Istniejące pomoce ewidencyjne mają przede wszystkim charakter pomocy wyższego rzędu, brak natomiast systematycznej i jednolitej ewidencji w rozumieniu archiwalnym, na podstawie której można byłoby chociażby określić rozmiary zasobu. Orientację w zasobie materiałów aktowych i nagrań zapewniają tematyczne katalogi kartkowe i częściowe 
sumariusze oraz dostępne również poprzez stronę internetową ośrodka elektroniczne wyszukiwarki obejmujące część nagrań dźwiękowych i materiałów prasowych Sekretariatu Stanu Stolicy Apostolskiej. Przed kilku laty podjęto też ewidencjonowanie bogatego zbioru fotografii w tematycznej bazie Zeus. Z kolei część archiwaliów uznanych za najcenniejsze została wprowadzona do bazy Musnet. Baza ta służy jednak przede wszystkim do ewidencjonowania obiektów muzealnych i cymeliów, co w pewien sposób zaciera granicę pomiędzy zasobem archiwum i biblioteki.

$\mathrm{W}$ poprzednich latach rozpoczęto digitalizację zasobu aktowego oraz materiałów audiowizualnych i fotografii. W trakcie digitalizacji nagrań niejednokrotnie natrafiano na problemy ze względu na wady techniczne i uszkodzenie taśmy magnetycznej bądź błędy w zapisie analogowym. Równie istotnym problemem okazał się rzadko spotykany współcześnie format analogowych kaset w systemie Beta. Wiele firm oferuje digitalizację popularnych kaset VHS, jednak w przypadku nośników Beta możliwości odtworzenia i przeniesienia zawartości do formatu cyfrowego są znacznie ograniczone.

Po dokonaniu przeglądu zasobu, w porozumieniu z dyrektorem ośrodka ks. Andrzejem Dąbrowskim ustalono podział materiałów archiwalnych na odrębne zespoły i przygotowano harmonogram prac. Następnie rozpoczęto systematyczną ewidencję zasobu w programie Excel/Calc. Jednolita forma ewidencji $\mathrm{w}$ arkuszu kalkulacyjnym poza prostą, niewymagającą specjalnego szkolenia obsługą i wygodną możliwością wyszukiwania informacji umożliwia łatwą migrację danych do bardziej zaawansowanych programów. Ma to znaczenie zarówno ze względów organizacyjnych, jak i w kontekście dążeń Naczelnej Dyrekcji Archiwów Państwowych do włączenia współpracujących z nią ośrodków polonijnych do Zintegrowanego Systemu Informacji Archiwalnej. Pod koniec pobytu rozpoczęto przepakowywanie materiałów aktowych do teczek i pudeł bezkwasowych oraz ich opisywanie.

W zamierzeniach ośrodka prace nad opracowaniem i technicznym zabezpieczeniem zasobu mają być prowadzone przy współudziale studentów archiwistyki w ramach obowiązujących ich praktyk. Tym razem w pracach na etapie ewidencji uczestniczyły dwie studentki z Uniwersytetu Papieskiego Jana Pawła II w Krakowie, przebywające w Rzymie w ramach programu Erasmus. 